\title{
How Does Live Yeast Differ from Sodium Bicarbonate to Stabilize Ruminal pH in High-Yielding Dairy Cows?
}

\author{
J. P. Marden, ${ }^{*} \dagger \ddagger$ C. Julien, ${ }^{*} \dagger \ddagger$ V. Monteils, ${ }^{\star} \dagger \ddagger$ E. Auclair, $\S$ R. Moncoulon, ${ }^{*} \dagger \ddagger$ and C. Bayourthe ${ }^{*} \dagger{ }^{1}$ \\ *INRA, and \\ †Université de Toulouse, INPT-ENSAT, UMR 1289 TANDEM, F-31326 Castanet-Tolosan, France \\ łENVT, UMR 1289 TANDEM, F-31076 Toulouse, France \\ $\S$ Lesaffre Feed Additives, 90 rue de Lille, F-59520 Marquette-Lez-Lille, France
}

\begin{abstract}
The objectives of this study were to evaluate the capacity of 2 dietary feed additives, sodium bicarbonate and live yeast Saccharomyces cerevisiae (strain Sc 47), in optimizing ruminal $\mathrm{pH}$ in dairy cows and to determine their modes of action. Three early lactating Holstein cows, fitted with ruminal cannulas, were allocated in a $3 \times 3$ Latin square design. They were given a total mixed ration as control diet (CD) at a daily feeding rate of $28.0 \mathrm{~kg}$ of dry matter $(\mathrm{DM}) / \mathrm{cow}$ supplemented with $150 \mathrm{~g} / \mathrm{d}$ of sodium bicarbonate (SBD) or $5 \mathrm{~g} / \mathrm{d}$ of live yeast (YD) during a 21-d experimental period (14 d of diet adaptation, 4 consecutive days of measurement and sampling and $3 \mathrm{~d}$ of transition). The $\mathrm{pH}$ and redox potential $\left(\mathrm{E}_{h}\right)$ were measured from $1 \mathrm{~h}$ before feeding to $8 \mathrm{~h}$ after feeding at 1 -h intervals, and samples of ruminal fluid were taken at $0,2,4,6$, and $8 \mathrm{~h}$ after feeding for the determination of volatile fatty acids and lactate concentrations. Total tract apparent digestibility of the diet was also determined. Ruminal $\mathrm{pH}$ fluctuated between 6.53 at feeding and 5.57 at $5 \mathrm{~h}$ postfeeding. Mean $\mathrm{pH}$ was greater with SBD (6.21) and YD (6.14) compared with CD (5.94), showing that both additives had a $\mathrm{pH}$ stabilization effect. The $\mathrm{E}_{h}$ varied from -88 $\mathrm{mV}$ at $1 \mathrm{~h}$ before feeding to $-165 \mathrm{mV}$ at $1 \mathrm{~h}$ after feeding. Mean $\mathrm{E}_{h}$ and Clark's Exponent $(\mathrm{rH})$ were lower with YD (-149 $\mathrm{mV}$ and 7.31 , respectively) than with SBD $(-137 \mathrm{mV}$ and 7.85 , respectively) and CD (-115 $\mathrm{mV}$ and 8.05 , respectively), indicating that the yeast strengthened the reducing power of the milieu. Total volatile fatty acids were greater in SBD $(95.3 \mathrm{~m} M)$ and YD $(99.4 \mathrm{~m} M)$ compared with CD $(85.3 \mathrm{~m} M)$. Acetate concentration was greater in SBD $(60.8 \mathrm{mM})$ and YD $(59.1 \mathrm{mM})$ compared with CD $(53.2 \mathrm{mM})$. Propionate concentration was greater in YD $(25.8 \mathrm{mM})$ than in SBD $(20.0 \mathrm{~m} M)$ and $\mathrm{CD}(18.0 \mathrm{~m} M)$. Butyrate remained
\end{abstract}

Received November 23, 2007.

Accepted April 22, 2008.

${ }^{1}$ Corresponding author: bayourth@ensat.fr constant between diets. Mean total lactate concentrations were $16.5,12.2$, and $5.4 \mathrm{~m} M$ for $\mathrm{CD}$, SBD, and YD, respectively, with a $67 \%$ decrease with YD. Total tract organic matter digestibility was greater for YD (66.6\%) compared with SBD (61.7\%) and CD (62.2\%). The neutral detergent fiber digestibility was greater with YD (41.6\%) compared with SBD (34.3\%) and CD $(29.6 \%)$, whereas acid detergent fiber digestibility was greatest in YD (32.3\%), intermediate in SBD (24.4\%), and lowest in CD (18.1\%). By inducing a lower ruminal $\mathrm{E}_{h}$ and $\mathrm{rH}$, live yeast prevented accumulation of lactate and allowed better fiber digestion, whereas sodium bicarbonate seemed to act only as an exogenous buffer.

Key words: live yeast, sodium bicarbonate, ruminal $\mathrm{pH}$, redox potential

\section{INTRODUCTION}

Modern feeding strategies have changed from primarily forage-based to progressively more readily fermentable carbohydrate (RFC) feedstuffs in dairy rations to meet the increasing milk production of highproducing animals. These practices favor the use of silages with a high acid content, low fiber diets with reduced particle size, and high levels of concentrates (Peyraud and Apper-Bossard, 2006). As a result, they can lead to the appearance of digestive disorders such as subacute ruminal acidosis (SARA) in dairy cattle if appropriate precautions are not taken. Excessive intake of RFC usually implies a temporal decrease in ruminal $\mathrm{pH}$ after feeding because of the accumulation of VFA and lactic acid in the rumen (Russell and Hino, 1985; Nocek, 1997). Under normal circumstances, the primary means to counteract acidification of the milieu is the production of saliva, which has a reliable impact on buffering capacity of the rumen (Maekawa et al., 2002) although feedstuffs have their own inherent buffering characteristics (Giger-Reverdin et al., 1999). However, in the presence of high-RFC-based diets, saliva outflow is considerably reduced causing incomplete ensalivation of feed entering the rumen (Owens et al., 1998). The limited saliva production cannot fulfill its 
buffering role and fails in preventing an important drop in ruminal $\mathrm{pH}$, thereby causing SARA.

To minimize the occurrence of ruminal acidosis, dairy nutritionists usually choose to supplement dietary buffers, especially where feeding conditions include large amounts of RFC. Commonly used as an exogenous buffer, sodium bicarbonate (SB) is involved in the stabilization of ruminal $\mathrm{pH}$ in cows that can potentially suffer from ruminal acidosis (Meschy et al., 2004). This chemical feed additive is characterized by an acid dissociation constant $\left(\mathrm{pK}_{a}=6.25\right)$, which is close to the normal rumen $\mathrm{pH}$. Therefore, $\mathrm{SB}$ is generally recognized as an efficient buffer because of its high acid-consuming capacity in the rumen, and its mode of action is well documented (Erdman, 1988; Russell and Chow, 1993).

For the last 2 decades, the utilization of new feed additives such as the probiotic yeast Saccharomyces cerevisiae has gained considerable interest. According to some researchers (Williams et al., 1991), positive production responses were accompanied by stabilization of ruminal $\mathrm{pH}$ often attributed to the lack of accumulation of lactate in the rumen thus preventing ruminal acidosis. To gain better insight into the mode of action of live yeast on ruminal fermentation, Mathieu et al. (1996) and Chaucheyras-Durand and Fonty (2002) went a step further by measuring another ruminal physicochemical parameter, the redox potential $\left(\mathbf{E}_{h}\right)$. By integrating $\mathrm{E}_{h}$ and $\mathrm{pH}$ in the Nernst equation, the Clark's Exponent $(\mathbf{r H})$ can be calculated, thereby providing a different view of the mechanisms involved in the stabilization of ruminal $\mathrm{pH}$. To our knowledge, no $\mathrm{E}_{h}$ data were recorded in studies dealing with SBsupplemented diets for ruminants. Furthermore, only few references relative to the comparison of SB and the probiotic yeast are available (Quigley et al., 1992; Galip, 2006). Consequently, the objectives of this study were to observe and compare the effects of a chemical buffering substance and a live microbial additive on 1) the rumen physicochemical measurements and calculation $\left(\mathrm{pH}, \mathrm{E}_{h}\right.$, and $\left.\left.\mathrm{rH}\right), 2\right)$ the rumen fermentation profile, and 3) the total tract apparent digestibility of the diet, to acquire a better understanding of the mechanisms of action involved in the stabilization of ruminal $\mathrm{pH}$.

\section{MATERIALS AND METHODS}

\section{Animals, Experimental Design, and Diets}

Three early-lactating Holstein cows (mean milk production of $45 \mathrm{~kg} / \mathrm{d}$ per cow) fitted with permanent ruminal cannulas were used. Cannulation techniques provided for humane treatment of cows, adhered to locally approved procedures, and were similar to those
Table 1. Composition of the control diet (CD) on a DM basis (\%)

\begin{tabular}{lc}
\hline Item & \\
\hline Ingredient & \\
Corn silage & 51.5 \\
Dehydrated alfalfa & 5.7 \\
Concentrate, ${ }^{2} 46 \% \mathrm{CP}$ & 17.95 \\
Concentrate, ${ }^{20 \%} \mathrm{CP}$ & 17.95 \\
Ground corn & 6.0 \\
Mineral vitamin $\mathrm{mix}^{3}$ & 0.90 \\
Nutrient analysis & \\
DM & 57.1 \\
OM & 88.3 \\
NDF & 37.8 \\
ADF & 19.9 \\
CP & 18.7 \\
Starch & 21.6 \\
NE & Mcal/kg of DM \\
\end{tabular}

${ }^{1}$ On a DM basis (\%): 40.1 solvent-extracted canola meal, 19.1 soybean meal, 27.5 tanned soybean meal, 3.6 sunflower meal, 3.5 urea, 3.2 corn grain, 2.0 sugarcane molasses, 0.5 salt, 0.5 trace mineral premix $(15 \mathrm{mg} / \mathrm{kg}$ of $\mathrm{Cu}$ sulfate, $6,000 \mathrm{IU} / \mathrm{kg}$ of vitamin A, 2,000 IU/kg vitamin $\mathrm{D}_{3}$, and $15 \mathrm{mg} / \mathrm{kg}$ of vitamin $\mathrm{E}$ ).

${ }^{2}$ On a DM basis (\%): 25.0 wheat bran, 20.0 solvent-extracted canola meal, 15.0 corn grain, 13.0 tanned soybean meal, 11.1 ground corn, 10.4 ground wheat, 2.1 calcium carbonate, 2.0 sugarcane molasses, 0.5 salt, 0.5 Ucx bovine flavor (Inzo, France), 0.4 trace mineral pre$\mathrm{mix}(15 \mathrm{mg} / \mathrm{kg}$ of $\mathrm{Cu}$ sulfate, $6,000 \mathrm{IU} / \mathrm{kg}$ of vitamin A, 2,000 IU/kg vitamin $\mathrm{D}_{3}$, and $15 \mathrm{mg} / \mathrm{kg}$ of vitamin $\mathrm{E}$ ).

${ }^{3}$ Containing P (40 g/kg), Ca (260 g/kg), Mg (50 g/kg), Na (120 g/kg), $\mathrm{Zn}(5 \mathrm{~g} / \mathrm{kg})$, Mn (4 g/kg), I (40 mg/kg), Co (20 mg/kg), Se (20 mg/kg), $\mathrm{Cu}(1 \mathrm{mg} / \mathrm{kg})$, vitamin A (450,000 IU/kg), vitamin $\mathrm{D}_{3}(100,000 \mathrm{IU} / \mathrm{kg})$, and vitamin $\mathrm{E}(1.5 \mathrm{~g} / \mathrm{kg})$.

described by Streeter et al. (1990). Cows were kept in individual pens with free access to water. They were assigned to 3 treatments: a control diet (CD), a sodium bicarbonate diet (SBD), and a yeast $\operatorname{diet}(\mathbf{Y D})$, in a 3 $\times 3$ Latin square design. The CD consisted of a TMR (Table 1) and was offered twice daily in equal portions at 0900 and $1700 \mathrm{~h}$. During each 21-d experimental period (14 d of adaptation to the diet, $4 \mathrm{~d}$ of measurement, and a 3 -d transition phase), the daily feeding rate was adjusted at $28.0 \mathrm{~kg} / \mathrm{cow}$ on a DM basis, to avoid sorting and orts. The YD and SBD were composed of CD supplemented with $5 \mathrm{~g}$ of live Saccharomyces cerevisiae $\left(10^{10} \mathrm{cfu} / \mathrm{g}\right.$ of DM, BIOSAF Sc 47 , Lesaffre Feed Additives, Marquette-Lez-Lille, France) or $150 \mathrm{~g}$ of SB, respectively. The recommended yeast and SB doses were top-dressed on the TMR during the morning meal.

\section{Measurements, Sampling, and Calculations}

Ruminal Physicochemical Measurements. During 4 consecutive days, for each cow, ruminal $\mathrm{pH}$ and $\mathrm{E}_{h}$ were recorded every hour from $1 \mathrm{~h}$ before the morning meal $\left(\mathrm{T}_{-1}\right)$ to $8 \mathrm{~h}$ after $\left(\mathrm{T}_{1}\right.$ to $\left.\mathrm{T}_{8}\right)$. The sampling device allowed continuous measurements of $\mathrm{pH}$ and $\mathrm{E}_{h}$ under anaerobic conditions as described by Marden et al. (2005). It consisted of a ring-shaped lead filter, covered 
on both sides with a sieve cloth. The filter was placed in the ventral side of the rumen to benefit maximum ruminal contractions. Ruminal fluid was pumped out of the rumen by a peristaltic pump (Gilson, Minipuls 2, Viliers Le Bel, France) into a thermostatic vessel maintained at $39^{\circ} \mathrm{C}$. This system also allowed simultaneous and representative sampling of ruminal fluid for analysis. Animals rapidly became accustomed to the instrument and ate, ruminated, and behaved normally so that measurements could be taken $1 \mathrm{~h}$ after introduction of the device.

The $\mathrm{pH}, \mathrm{E}_{h}$, and temperature measurements were carried out using 3 electrodes connected to a digital $\mathrm{pH}$ meter (model 713, Metrohm, Herisau, Switzerland): a glass $\mathrm{pH}$ electrode (combined electrode with diaphragm DG SC and with $\mathrm{Ag}-\mathrm{AgCl}$ as reference), an $\mathrm{E}_{h}$ platinum electrode (Pt SC), and a platinum thermoelectrode (Pt 100 RNEA911 - Pt100).

Calculations. The $\mathrm{E}_{h}$ is a measure of the ability of a solution to accept or donate electrons and corresponds to the potential difference $(\mathrm{mV})$ between a platinum electrode and a standard hydrogen electrode. Because an $\mathrm{Ag}-\mathrm{AgCl}$ reference electrode was used, all measured values were corrected using the formula: $\mathrm{E}_{h}=\mathrm{E}_{0}+\mathrm{C}$, where $\mathrm{E}_{0}$ is the potential of the platinum electrode and $\mathrm{C}$ is the potential of the $\mathrm{Ag}-\mathrm{AgCl}$ reference electrode compared with the Standard Hydrogen Electrode (SHE); that is, $+199 \mathrm{mV}$ at $39^{\circ} \mathrm{C}$.

The Clark's Exponent yields a true index of the reducing power in a given milieu. It is calculated by integrating both $\mathrm{pH}$ and $\mathrm{E}_{h}$ values in the Nernst's equation: $\mathrm{rH}$ $=\mathrm{E}_{h}(\mathrm{mV}) / 30+2 \mathrm{pH}$ (Marounek et al., 1987).

Fermentation Parameters. For each treatment, a $10-\mathrm{mL}$ ruminal fluid sample was collected at the exit of the measuring cell at 2-h intervals from the time of the morning meal to $8 \mathrm{~h}$ postfeeding $\left(\mathrm{T}_{0}\right.$ to $\mathrm{T}_{8}$ ). Each sample was preserved by the addition of $1 \mathrm{~mL}$ of mercuric chloride $(2 \% \mathrm{wt} / \mathrm{vol})$ and frozen at $-18^{\circ} \mathrm{C}$ for subsequent VFA and lactate determinations.

Apparent Total Tract Digestibility of Diet. On a daily basis, feed consumption was recorded and representative samplings of feed were taken from $\mathrm{d} 15$ to 17. Total fecal material from each individual cow was collected from d 16 to 18; feces were removed once daily for weighing, mixing, and sampling. Fecal samples (200 g) were dried at $60^{\circ} \mathrm{C}$ for $48 \mathrm{~h}$ and ground through a 1-mm screen for subsequent DM, OM, NDF, and ADF determinations. Apparent nutrient digestibilities of the diet were calculated from the different measurements.

\section{Chemical Analyses}

The concentrations of VFA were determined using the gas chromatographic method of Playne (1985) modified as follows: the ruminal samples were first centrifuged at $4,000 \times g$ for $20 \mathrm{~min}$ to separate the liquid phase. For protein removal, $1 \mathrm{~mL}$ of supernatant was mixed with $200 \mu \mathrm{L}$ of $25 \%$ metaphosphoric acid and further centrifuged at 20,000 $\times \mathrm{g}$ for $15 \mathrm{~min}$. One milliliter of supernatant was added to $200 \mu \mathrm{L}$ (1\% $\mathrm{vol} / \mathrm{vol}$ ) of 4-methylvaleric acid as internal standard, and $1 \mu \mathrm{L}$ of the mixture was then injected into a gas chromatograph (Model 5890 Series II equipped with a flame-ionization detector, Hewlett-Packard, Avondale, PA).

Total lactate (DL-lactate) was determined using a commercial kit (cat. no. 11112821 035, Boehringer Mannheim/R-Biopharm, St. Didier au Mont d'Or, France). Dry matter and OM content of samples were determined by oven drying at $104^{\circ} \mathrm{C}$ for $24 \mathrm{~h}(48 \mathrm{~h}$ for feces) and by ashing at $550^{\circ} \mathrm{C}$ for $12 \mathrm{~h}$, respectively. The $\mathrm{NDF}$ and ADF contents were sequentially determined using a Fibertec apparatus (Velp Scientifica, Usmate, Italy) according to the method described by Van Soest et al. (1991) and corrected for ash content. Fifty microliters of heat stable a-amylase (A3306, Sigma-Aldrich Chimie, Saint Quentin Fallavier, France) was used for NDF analyses and sodium sulfite was not used.

\section{Statistical Analyses}

All data were analyzed using the SPSS software (SPSS Version 13.0 for Windows, SPSS Inc., Chicago, IL) and were reported as mean values with standard error of the mean. Responses of $\mathrm{pH}, \mathrm{E}_{h}, \mathrm{rH}$, total and individual VFA concentrations, and lactate contents were analyzed using a repeated-measures model that included as main plot the effects of cow, treatment, and period whereas sampling time and the interaction between treatment and sampling time were considered in the subplot, using the following model:

$$
\mathrm{Y}_{\mathrm{ijkl}}=\mu+\mathrm{P}_{\mathrm{i}}+\mathrm{C}_{\mathrm{j}}+\operatorname{Trt}_{\mathrm{k}}+\mathrm{t}_{1}+(\operatorname{Trt} \times \mathrm{t})_{\mathrm{kl}}+\varepsilon_{\mathrm{ijkl}},
$$

where $\mathrm{Y}$ is the dependent variable, $\mu$ the overall mean, $\mathrm{P}_{\mathrm{i}}$ the period effect, $\mathrm{C}_{\mathrm{j}}$ the cow effect, Trt $_{\mathrm{k}}$ the treatment effect, $t_{1}$ the sampling time effect, $(\text { Trt } \times t)_{k l}$ the interaction between treatment and sampling time, and $\varepsilon_{\mathrm{ijkl}}$ the residual error. Differences between treatment effects were assessed by pairwise comparisons (Tukey's test).

Data for digestibility were analyzed with a GLM model including the effects of treatment, period and cow. The model used was:

$$
\mathrm{Y}_{\mathrm{ijk}}=\mu+\mathrm{P}_{\mathrm{i}}+\mathrm{C}_{\mathrm{j}}+\operatorname{Trt}_{\mathrm{k}}+\varepsilon_{\mathrm{ijk}}
$$

where $\mathrm{Y}$ is the dependent variable, $\mu$ the overall mean, $\mathrm{P}_{\mathrm{i}}$ the period effect, $\mathrm{C}_{\mathrm{j}}$ the cow effect, $\operatorname{Trt}_{\mathrm{k}}$ the treat- 
Table 2. Effect of live yeast and sodium bicarbonate on ruminal physicochemical and fermentation parameters

\begin{tabular}{|c|c|c|c|c|c|c|c|}
\hline \multirow[b]{2}{*}{ Item $^{1}$} & \multicolumn{3}{|c|}{ Treatment $^{2}$} & \multirow[b]{2}{*}{ SEM } & \multicolumn{3}{|c|}{$P$-value ${ }^{3}$} \\
\hline & $\mathrm{CD}$ & SBD & YD & & Trt & $\mathrm{t}$ & $\operatorname{Trt} \times \mathrm{t}$ \\
\hline $\mathrm{pH}$ & $5.94^{\mathrm{b}}$ & $6.21^{\mathrm{a}}$ & $6.14^{\mathrm{a}}$ & 0.02 & 0.03 & $<0.001$ & 0.04 \\
\hline $\mathrm{E}_{h}, \mathrm{mV}$ & $-115^{\mathrm{a}}$ & $-137^{\mathrm{b}}$ & $-149^{\mathrm{c}}$ & 5.3 & 0.04 & $<0.001$ & 0.01 \\
\hline $\mathrm{rH}$ & $8.05^{\mathrm{a}}$ & $7.85^{\mathrm{a}}$ & $7.31^{\mathrm{b}}$ & 0.13 & 0.02 & $<0.001$ & 0.05 \\
\hline
\end{tabular}

${ }^{a-c}$ Means within a row with different superscripts differ $(P<0.05)$.

${ }^{1} \mathrm{E}_{h}=$ redox potential; $\mathrm{rH}=$ Clark's Exponent.

${ }^{2}$ Treatments: $\mathrm{CD}=$ control diet; $\mathrm{SBD}=\mathrm{CD}+150 \mathrm{~g} / \mathrm{d}$ sodium bicarbonate; $\mathrm{YD}=\mathrm{CD}+5 \mathrm{~g} / \mathrm{d}$ of live yeast (Sc 47).

${ }^{3} \operatorname{Trt}=$ treatment effect; $\mathrm{t}=$ time effect; Trt $\times \mathrm{t}=$ treatment time interaction effect.

ment effect, and $\varepsilon_{\mathrm{ijkl}}$ the residual error. Differences between treatment effects were assessed by pairwise comparisons (Tukey's test). Differences were considered significant at $P<0.05$ and trends were discussed at $P<0.10$.

\section{RESULTS}

\section{Ruminal $\mathrm{pH}$}

The ruminal $\mathrm{pH}$ in animals fed $\mathrm{CD}$ varied between 6.41 and 5.57 (Figure 1a) with a mean $\mathrm{pH}$ of 5.94. With $\mathrm{YD}$, the $\mathrm{pH}$ reached a peak at 6.53 and a nadir value of 5.90, with a mean of 6.14. With SBD, the $\mathrm{pH}$ fluctuated between 6.51 and 5.94 with a mean value of 6.21 . Differences $(P=0.03)$ were observed between the mean $\mathrm{pH}$ values obtained with YD and SBD diets when compared with $\mathrm{CD}$. A treatment $\times$ time interaction from $\mathrm{T}_{3}$ to $\mathrm{T}_{8}$ was recorded (Table 2). No significant effect was found between YD and SBD. When considering all 3 diets, the evolution of the $\mathrm{pH}$ curves showed a similar trend with a decrease at $1 \mathrm{~h}$ postfeeding $\left(\mathrm{T}_{1}\right)$ that lasted for the following 4-h period to $\mathrm{T}_{5}$. Beyond $5 \mathrm{~h}$ postfeeding and until the end of the measuring period, $\mathrm{pH}$ values remained below 6 for $\mathrm{CD}$, whereas with $\mathrm{YD}$ and $\mathrm{SBD}$, the $\mathrm{pH}$ values gradually returned to their initial values.

\section{Ruminal Redox Potential and $\mathrm{rH}$}

The redox potential of the ruminal fluid varied between -88 and $-134 \mathrm{mV}$ with a mean value of -115 $\mathrm{mV}$ for $\mathrm{CD}$, between -102 and $-155 \mathrm{mV}$ with a mean of $-137 \mathrm{mV}$ for SBD, and between -109 and $-165 \mathrm{mV}$ with a mean of $-149 \mathrm{mV}$ for YD. The different trends of the curves (Figure 1b) were due to a significant treatment $x$ time interaction between $\mathrm{T}_{3}$ and $\mathrm{T}_{8}$. The mean $\mathrm{E}_{h}$ values of all diets differed (Table 2). When compared with $\mathrm{CD}$, the decrease in rumen $\mathrm{E}_{h}$ was more pronounced in YD than in SBD (34 vs. $22 \mathrm{mV}$, respectively). The calculated mean $\mathrm{rH}$ was lower in YD (7.31) compared with CD (8.05) and SBD (7.85).

\section{Ruminal VFA and Lactate Concentrations}

Total VFA concentrations were on average $53.2 \mathrm{mM}$ for CD, $60.8 \mathrm{~m} M$ for SBD, and $59.1 \mathrm{~m} M$ for YD (Table 3). Treatments SBD and YD resulted in greater total VFA concentrations than CD. Mean acetate concentration was greater in SBD $(60.8 \mathrm{~m} M)$ and YD $(59.1 \mathrm{~m} M)$ than in $\mathrm{CD}(53.2 \mathrm{~m} M)$ from $\mathrm{T}_{4}$ to $\mathrm{T}_{8}$. Mean propionate concentration was greater in YD $(25.8 \mathrm{mM})$ compared with CD $(18.0 \mathrm{~m} M)$ and SBD $(20.0 \mathrm{mM})$. From $\mathrm{T}_{0}$ to $\mathrm{T}_{8}$, propionate concentration was greater in YD than in SBD and CD. A significant treatment $\times$ time interaction was observed for acetate and propionate, respectively. Butyrate concentrations did not differ among treatments. The total lactate concentrations ranged from 4.9 to $32.0 \mathrm{~m} M$ in $\mathrm{CD}$, from 3.0 to $30.1 \mathrm{~m} M$ in SBD, and from 1.1 to $11.9 \mathrm{~m} M$ in YD. The average concentration in YD $(5.40 \mathrm{~m} M)$ was lower than in CD $(16.5 \mathrm{mM})$ and SBD $(12.2 \mathrm{mM})$. A significant treatment $\times$ time interaction was recorded for total lactate concentration.

\section{Apparent Total Tract Digestibility}

The apparent DM and OM digestibilities of the 3 diets were similar. There was no more than a trend $(P$ $=0.09$ ) for the advantage of YD compared with SBD or CD. Total tract NDF digestibility was greater in YD compared with SBD and CD (Table 4). Total tract ADF digestibility in YD and SBD were greater than in CD.

\section{DISCUSSION}

The high-yielding cows used in this trial were fed a concentrate diet and the large amount of RFC fermented in the rumen was expected to favor SARA. In fact, $\mathrm{CD}$ induced a ruminal $\mathrm{pH}$ below the threshold value of 6 from $3 \mathrm{~h}$ postfeeding until the end of the measuring 
period. These observations reflected an acidotic state of the animals according to Sauvant et al. (1999). It must be pointed out that $\mathrm{pH}$ measurements were recorded in our trial $1 \mathrm{~h}$ before the morning meal to $8 \mathrm{~h}$ after feeding. Therefore, the initial $\mathrm{pH}$ value at $\mathrm{T}_{-1}$ was obviously not reached at $\mathrm{T}_{8}$ because the 9-h measuring period reflected only a short part of the diurnal pattern of $\mathrm{pH}$ variations occurring in the rumen. Mackie et al. (1978) in sheep and Oetzel (2000) in cows reported that an 8-h interval between 2 meals did not allow the ruminal $\mathrm{pH}$ to return to its original value, and that the initial $\mathrm{pH}$ was only recovered after the nocturnal 16 -h interval.

Incorporating live yeast or SB in the $\mathrm{CD}$ resulted in a significant stabilization of ruminal $\mathrm{pH}$. These observations were in accordance with those of Fiems et al. (1993) and Erdman (1988) for live yeast and SB supplementation, respectively. Generally, in a diet containing a high proportion of $\mathrm{RFC}$, a $\mathrm{pH}$ decrease is systematically associated with an increase in VFA and lactate concentrations (Patra et al., 1996). In the present study, the greater $\mathrm{pH}$ observed in YD and SBD was associated with an increase in total VFA concentrations. Live yeast supplementation led to a significant decrease in ruminal lactate contents but SB addition had no effect. As a consequence, the stabilization of $\mathrm{pH}$ observed with YD could also have been due to a decrease in ruminal lactate concentration. On the contrary, the stabilization of $\mathrm{pH}$ with SBD was not associ-

(a)

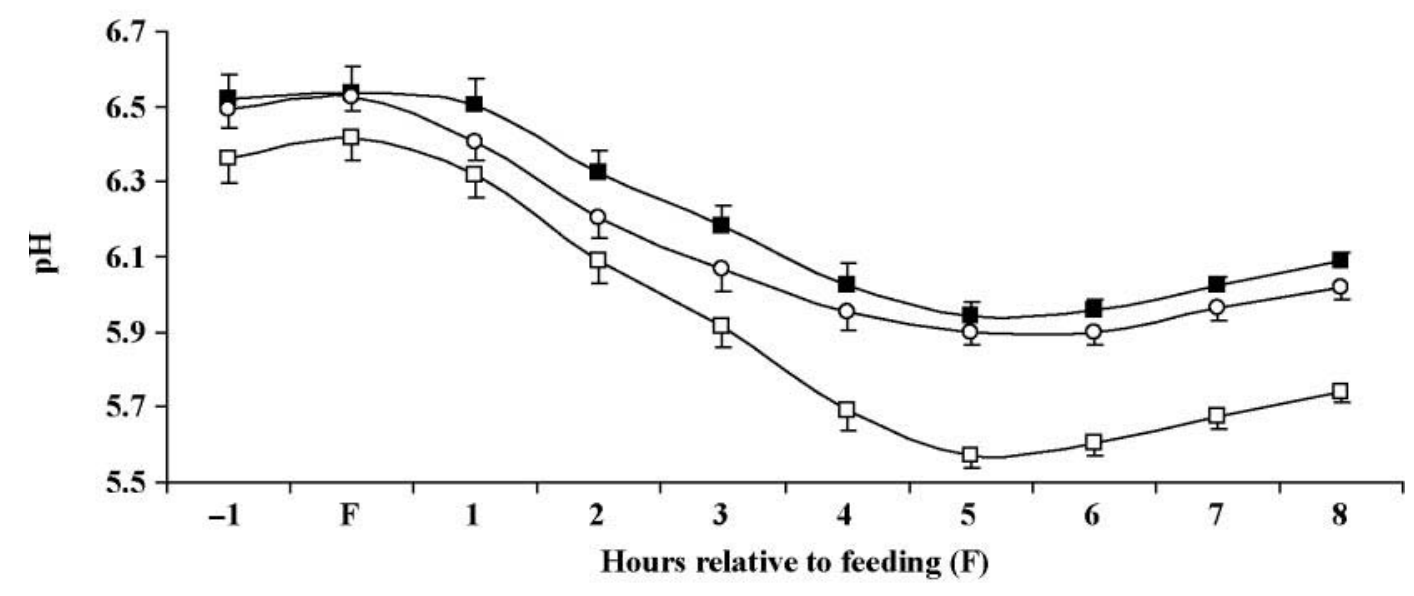

$\rightarrow-$ Control Diet (CD)

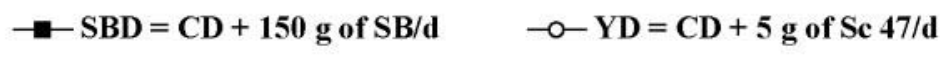

(b)

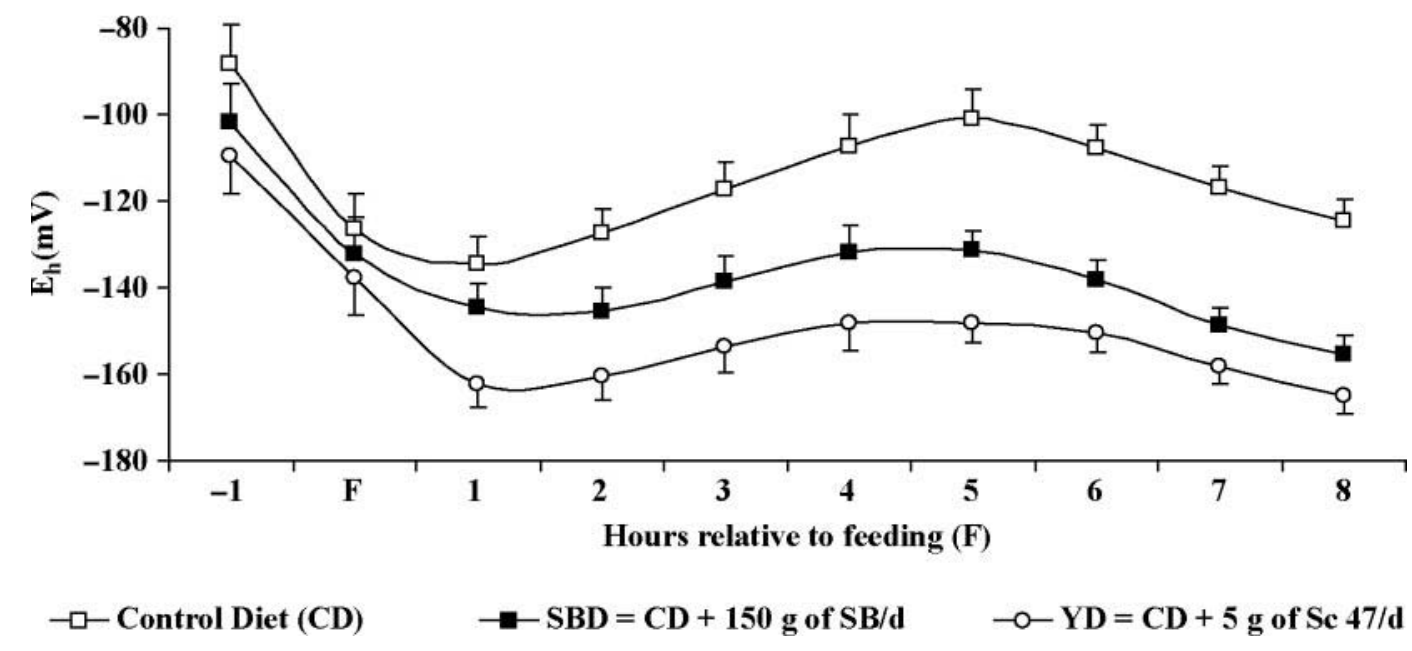

Figure 1. Effect of live yeast and sodium bicarbonate on the evolution of ruminal $\mathrm{pH}$ and redox potential $\left(\mathrm{E}_{h}\right)$. Vertical bars show $\mathrm{SE}$. 
Table 3. Effects of live yeast, sodium bicarbonate, and sampling time on ruminal VFA and lactate concentrations

\begin{tabular}{|c|c|c|c|c|c|c|c|}
\hline \multirow[b]{2}{*}{ Item } & \multicolumn{3}{|c|}{ Treatment $^{1}$} & \multirow[b]{2}{*}{ SEM } & \multicolumn{3}{|c|}{$P$-value ${ }^{2}$} \\
\hline & $\mathrm{CD}$ & $\mathrm{SBD}$ & YD & & Trt & $\mathrm{t}$ & Trt $\times t$ \\
\hline Total VFA, mM & $85.3^{\mathrm{b}}$ & $95.3^{\mathrm{a}}$ & $99.4^{\mathrm{a}}$ & 1.5 & 0.04 & $<0.001$ & 0.33 \\
\hline \multicolumn{8}{|l|}{ Acetate, $\mathrm{m} M$} \\
\hline $0 \mathrm{~h}$ & 39.4 & 46.1 & 45.3 & & & & \\
\hline $2 \mathrm{~h}$ & $55.7^{\mathrm{b}}$ & $59.9^{\mathrm{ab}}$ & $61.7^{\mathrm{a}}$ & & & & \\
\hline $4 \mathrm{~h}$ & $57.2^{\mathrm{c}}$ & $66.4^{\mathrm{a}}$ & $61.9^{\mathrm{b}}$ & & & & \\
\hline $6 \mathrm{~h}$ & $57.4^{\mathrm{b}}$ & $66.7^{\mathrm{a}}$ & $64.5^{\mathrm{a}}$ & & & & \\
\hline $8 \mathrm{~h}$ & $56.1^{\mathrm{b}}$ & $64.7^{\mathrm{a}}$ & $62.2^{\mathrm{a}}$ & & & & \\
\hline Mean & $53.2^{\mathrm{b}}$ & $60.8^{\mathrm{a}}$ & $59.1^{\mathrm{a}}$ & 0.99 & 0.03 & $<0.001$ & 0.04 \\
\hline \multicolumn{8}{|l|}{ Propionate, $\mathrm{m} M$} \\
\hline $0 \mathrm{~h}$ & $12.5^{\mathrm{c}}$ & $14.3^{\mathrm{b}}$ & $17.0^{\mathrm{a}}$ & & & & \\
\hline $2 \mathrm{~h}$ & $18.9^{\mathrm{b}}$ & $19.8^{\mathrm{b}}$ & $23.7^{\mathrm{a}}$ & & & & \\
\hline $4 \mathrm{~h}$ & $20.1^{\mathrm{c}}$ & $22.6^{\mathrm{b}}$ & $29.0^{\mathrm{a}}$ & & & & \\
\hline $6 \mathrm{~h}$ & $20.4^{\mathrm{b}}$ & $22.2^{\mathrm{b}}$ & $31.0^{\mathrm{a}}$ & & & & \\
\hline $8 \mathrm{~h}$ & $18.0^{\mathrm{b}}$ & $20.9^{\mathrm{b}}$ & $28.5^{\mathrm{a}}$ & & & & \\
\hline Mean & $18.0^{\mathrm{b}}$ & $20.0^{\mathrm{b}}$ & $25.8^{\mathrm{a}}$ & 0.49 & $<0.01$ & $<0.001$ & 0.02 \\
\hline \multicolumn{8}{|l|}{ Butyrate, $\mathrm{m} M$} \\
\hline $0 \mathrm{~h}$ & 6.8 & 6.7 & 5.8 & & & & \\
\hline $2 \mathrm{~h}$ & $10.6^{\mathrm{a}}$ & $8.7^{\mathrm{b}}$ & $10.4^{\mathrm{a}}$ & & & & \\
\hline $4 \mathrm{~h}$ & 11.9 & 11.2 & 11.3 & & & & \\
\hline $6 \mathrm{~h}$ & 11.8 & 12.5 & 12.5 & & & & \\
\hline $8 \mathrm{~h}$ & 11.8 & 11.5 & 11.0 & & & & \\
\hline Mean & 10.6 & 10.1 & 10.2 & 0.25 & 0.35 & 0.14 & 0.48 \\
\hline \multicolumn{8}{|c|}{ Total lactate, $\mathrm{m} M$} \\
\hline $0 \mathrm{~h}$ & $8.7^{\mathrm{a}}$ & $4.8^{\mathrm{ab}}$ & $1.1^{\mathrm{b}}$ & & & & \\
\hline $2 \mathrm{~h}$ & $32.0^{\mathrm{a}}$ & $30.1^{\mathrm{a}}$ & $11.9^{\mathrm{b}}$ & & & & \\
\hline $4 \mathrm{~h}$ & $26.0^{\mathrm{a}}$ & $14.5^{\mathrm{b}}$ & $5.9^{\mathrm{b}}$ & & & & \\
\hline $6 \mathrm{~h}$ & 10.9 & 8.5 & 6.3 & & & & \\
\hline $8 \mathrm{~h}$ & $4.9^{\mathrm{a}}$ & $3.0^{\mathrm{ab}}$ & $1.6^{\mathrm{b}}$ & & & & \\
\hline Mean & $16.5^{\mathrm{a}}$ & $12.2^{\mathrm{a}}$ & $5.4^{\mathrm{b}}$ & 1.6 & 0.03 & $<0.001$ & 0.05 \\
\hline
\end{tabular}

ated with a lower lactate concentration. Therefore, SB may have stabilized the $\mathrm{pH}$ through its strong capacity to neutralize protons (Le Ruyet and Tucker, 1992).

Propionate concentration did not differ between CD and SBD. In contrast, it increased in YD, in agreement with Chademana and Offer (1990). Ruminal lactate concentration decreased, thereby confirming previous studies (Williams et al., 1991). With YD, the increase in propionate and decrease lactate concentrations seemed to reveal an enhanced conversion of lactate to propionate. The greater $\mathrm{pK}_{a}$ of propionate (4.87) compared with lactate (3.86) can therefore account for the observed ruminal $\mathrm{pH}$ stabilization.

Ruminal $\mathrm{pH}$ plays an important role in regulating the microbial ecosystem, especially for low-pH sensitive microorganisms such as cellulolytic bacteria

Table 4. Effect of live yeast and sodium bicarbonate on apparent total tract digestibility of the diet

\begin{tabular}{lccccc}
\hline & \multicolumn{3}{c}{ Treatment $^{1}$} & & \\
\cline { 2 - 4 } Apparent & CD & SBD & YD & SEM & $P$-value, Trt $^{2}$ \\
\hline digestibility (\%) & 59.0 & 58.5 & 64.0 & 1.8 & 0.09 \\
DM & 62.2 & 61.7 & 66.6 & 2.3 & 0.09 \\
NDF & $29.6^{\mathrm{b}}$ & $34.3^{\mathrm{b}}$ & $41.6^{\mathrm{a}}$ & 2.6 & 0.03 \\
ADF & $18.1^{\mathrm{c}}$ & $24.4^{\mathrm{b}}$ & $32.3^{\mathrm{a}}$ & 2.9 & 0.01 \\
\hline
\end{tabular}

${ }^{a-c}$ Means within a row with different superscripts differ $(P<0.05)$.

${ }^{1}$ Treatments: $\mathrm{CD}=$ control diet; $\mathrm{SBD}=\mathrm{CD}+150 \mathrm{~g} / \mathrm{d}$ sodium bicarbonate; $\mathrm{YD}=\mathrm{CD}+5 \mathrm{~g} / \mathrm{d}$ of live yeast ( $\mathrm{Sc}$ 47).

${ }^{2}$ Trt $=$ treatment effect. 
(Russell and Wilson, 1996). Although ruminal pH was stabilized with both supplements, the apparent fiber digestibility data suggest that YD favored the activity of cellulolytic bacteria. The lower NDF and ADF digestibility in SBD agrees with Mould and Orskov (1983) who indicated that buffering of $\mathrm{pH}$ with bicarbonate only partially restored ruminal cellulolysis in sheep fed a high-concentrate diet. Offer (1990) also reported that ruminal $\mathrm{pH}$ was not the sole parameter to affect bacterial activity.

Measurements of ruminal $\mathrm{E}_{h}$ are seldom reported in field or experimental conditions because of their high anaerobic requirements (Marden et al., 2005). Initially investigated in the rumen by Broberg (1958), $\mathrm{E}_{h}$ measurement and $\mathrm{rH}$ reflect the oxidizing or reducing state of a milieu with lower values indicating more reducing conditions. According to Barry et al. (1977), $\mathrm{E}_{h}$ varied in sheep from -150 to $-260 \mathrm{mV}$ during the feeding cycle with more reducing values at feeding and greater values postfeeding. The $\mathrm{rH}$ ranged from 6.3 to 8.6 in goat's rumen fluid (Marounek et al., 1982). In this trial, the $\mathrm{E}_{h}$ shifted to more negative values and the $\mathrm{rH}$ decreased more with YD compared with SBD. Because only few data are available concerning the effect of live yeast on ruminal $\mathrm{E}_{h}$ and $\mathrm{rH}$, comparison with the literature is difficult. The recorded $\mathrm{E}_{h}$ appeared to be in agreement with those of Mathieu et al. (1996) who also observed a more reducing ruminal environment when sheep were fed a yeast-supplemented diet. The ability of the live yeast to strengthen the reducing power of the ruminal milieu could explain the already reported improvement in growth and activity of lactate-consuming (Rossi et al., 1995) and cellulolytic bacterial populations (Chaucheyras et al., 1997). In doing so, the probiotic yeast supplement led to the stabilization of $\mathrm{pH}$ by the conversion of lactate to propionate and enhanced fiber digestion. In contrast, the reducing ruminal conditions reached with SBD provide no clear effect on lactateutilizing bacteria.

\section{CONCLUSIONS}

This study allowed differentiating between the modes of action of 2 dietary additives used when dairy cows are subjected to SARA. Supplementation with bicarbonate and live yeast had the same ability to stabilize ruminal $\mathrm{pH}$ after feeding. Sodium bicarbonate had smaller effects than live yeast on ruminal $\mathrm{E}_{h}$ and $\mathrm{rH}$, fermentation, and total tract digestibility, suggesting therefore that its main mode of action was to buffer excess acid in the rumen. Live yeast prevented the accumulation of lactate and allowed better fiber digestion by strengthening reducing conditions of ruminal environment.

\section{REFERENCES}

Barry, T. N., A. Thompson, and D. G. Armstrong. 1977. Rumen fermentation studies on two contrasting diets. 1. Some characteristics of the in vivo fermentation, with special reference to the composition of the gas phase, oxidation/reduction state and volatile fatty acid proportions. J. Agric. Sci. Camb. 89:183-195.

Broberg, G. 1958. Measurements of the redox potential in rumen contents. IV. In vivo measurements. Nord. Vet. Med. 10:263268.

Chademana, I., and N. W. Offer. 1990. The effect of dietary inclusion of yeast culture on digestion in the sheep. Anim. Prod. 50:483489.

Chaucheyras, F., L. Millet, B. Michalet-Doreau, G. Fonty, G. Bertin, and $\mathrm{Ph}$. Gouet. 1997. Effect of an addition of Levucell ${ }^{\mathbb{R}} \mathrm{SC}$ on the rumen microflora of sheep during adaptation to high starch diets. Page 82 (Suppl. 1-88) in Rowett Research Institute and INRA Symposium Proc., Evolution of the rumen microbial ecosystem, Aberdeen, UK.

Chaucheyras-Durand, F., and G. Fonty. 2002. Influence of a probiotic yeast (Saccharomyces cerevisiae CNCM I-1077) on microbial colonization and fermentations in the rumen of newborn lambs. Microb. Ecol. Health Dis. 14:30-36.

Erdman, R. A. 1988. Dietary buffering requirements of the lactating dairy cows: A review. J. Dairy Sci. 71:3246-3266.

Fiems, L. O., B. G. Cottyn, L. Dussert, and J. M. Vanacker. 1993. Effect of a viable yeast culture on digestibility and rumen fermentation in sheep fed different types of diets. Reprod. Nutr. Dev. 33:43-49.

Galip, N. 2006. Effect of supplemental yeast culture and sodium bicarbonate on ruminal fermentation and blood variables in rams. J. Anim. Physiol. Anim. Nutr. 90:446-452.

Giger-Reverdin, S., C. Duvaux-Ponter, D. Sauvant, C. Maaroufi, and F. Meschy. 1999. Variabilité des pouvoirs tampon et acidogène de 24 matières premières destinées au ruminants. Liaison avec la composition chimique. Renc. Rech. Rum. 6:95-98.

Le Ruyet, P., and W. B. Tucker. 1992. Ruminal buffers: Temporal effects on buffering capacity and $\mathrm{pH}$ of ruminal fluid from cows fed a high concentrate diet. J. Dairy Sci. 75:1069-1077.

Mackie, R. I., F. M. C. Gilchrist, A. M. Robberts, P. E. Hannah, and H. M. Schwartz. 1978. Microbiological and chemical changes in the rumen during the stepwise adaptation of sheep to high concentrate diets. J. Agric. Sci. 90:241-254.

Maekawa, M., K. A. Beauchemin, and D. A. Christensen. 2002. Effect of concentrate level and feeding management on chewing activities, saliva production, and ruminal $\mathrm{pH}$ of lactating dairy cows. J. Dairy Sci. 58:1165-1175.

Marden, J. P., C. Bayourthe, F. Enjalbert, and R. Moncoulon. 2005. A new device for measuring kinetics of ruminal $\mathrm{pH}$ and redox potential in dairy cow. J. Dairy Sci. 88:277-281.

Marounek, M., S. Bartos, and G. I. Kalachnyuk. 1982. Dynamics of the redox potential and $\mathrm{rH}$ of the rumen fluid of goats. Physiol. Bohemoslov. 31:369-374.

Marounek, M., P. Roubal, and S. Bartos. 1987. The redox potential, $\mathrm{rH}$ and $\mathrm{pH}$ values in the gastrointestinal tract of small ruminants. Physiol. Bohemoslov. 36:71-74.

Mathieu, F., J. P. Jouany, J. Senaud, J. Bohatier, G. Bertin, and M. Mercier. 1996. The effect of Saccharomyces cerevisiae and Aspergillus oryzae on fermentations in the rumen of faunated and defaunated sheep: Protozoal and probiotics interactions. Reprod. Nutr. Dev. 36:271-287.

Meschy, F., D. Bravo, and D. Sauvant. 2004. Méta-analyse des réponses de la vache laitière à la supplémentation en substances tampons. INRA Prod. Anim. 17:11-18.

Mould, F. L., and E. R. Orskov. 1983. Manipulation of rumen fluid $\mathrm{pH}$ and its influence on cellulolysis in sacco, dry matter degradation and the rumen microflora of sheep offered either hay or concentrate. Anim. Feed Sci. Technol. 10:1-14.

Nocek, J. E. 1997. Bovine acidosis: Implications on laminitis. J. Dairy Sci. 80:1005-1028. 
Oetzel, G. R. 2000. Clinical aspects of ruminal acidosis in dairy cattle. Pages 46-53 in 33rd Annual Conference Proc., American Association of Bovine Practitioners, Rapid City, SD.

Offer, N. W. 1990. Maximizing fiber digestion in the rumen: The role of yeast culture. Pages 79-86 in Biotechnology in the Feed Industry. T. P. Lyons, ed. Alltech Technical Publications, Nicholasville, KY.

Owens, F. N., D. S. Secrist, W. J. Hill, and D. R. Gill. 1998. Acidosis in cattle: A review. J. Anim. Sci. 76:275-286.

Patra, R. C., S. B. Lal, and D. Swarup. 1996. Biochemical profile of rumen liquor, blood, urine in experimental acidosis in sheep. Small Rumin. Res. 19:177-180.

Peyraud, J. L., and E. Apper-Bossard. 2006. L'acidose latente chez la vache laitière. INRA Prod. Anim. 19:79-92.

Playne, M. J. 1985. Determination of ethanol, volatile fatty acids, lactic acid and succinic acid in fermentation liquids by gas chromatography. J. Sci. Food Agric. 36:638-644.

Quigley, J. D., L. B. Wallis, H. H. Dowlen, and R. N. Heitmann. 1992. Sodium bicarbonate and yeast culture effects on ruminal fermentation, growth, and intake in dairy calves. J. Dairy Sci. 75:3531-3538.

Rossi, F., P. S. Cocconcelli, and F. Masoero. 1995. Effect of a Saccharomyces cerevisiae culture on growth and lactate utilization by the ruminal bacterium Megasphaera elsdenii. Ann. Zootech. 44:403-409.
Russell, J. B., and J. M. Chow. 1993. Another theory for the action of ruminal buffer salts: Decreased starch fermentation and propionate production. J. Dairy Sci. 76:826-830.

Russell, J. B., and T. Hino. 1985. Regulation of lactate production in Streptococcus bovis: A spiralling effect that contributes to rumen acidosis. J. Dairy Sci. 68:1712-1721.

Russell, J. B., and D. B. Wilson. 1996. Why are ruminal cellulolytic bacteria unable to digest cellulose at low pH? J. Dairy Sci. 79:1503-1509.

Sauvant, D., F. Meschy, and D. Mertens. 1999. Les composantes de l'acidose ruminale et les effets acidogènes des rations. INRA Prod. Anim. 12:49-60.

Streeter, M. N., D. G. Wagner, C. A. Hibberd, and F. N. Owens. 1990. Comparison of corn with four sorghum grain hybrids: Site and extent of digestion in steers. J. Anim. Sci. 68:3429-3440.

Van Soest, P. J., J. B. Robertson, and B. A. Lewis. 1991. Methods for dietary fibre, neutral detergent fiber and non-starch polysaccharides in relation to animal nutrition. J. Dairy Sci. 74:3583-3597.

Williams, P. E. V., C. A. G. Tait, G. M. Innes, and C. J. Newbold. 1991. Effects of the inclusion of yeast culture (Saccharomyces cerevisiae plus growth medium) in the diet of dairy cows on milk yield and forage degradation and fermentation patterns in the rumen of steers. J. Anim. Sci. 69:3016-3026. 